\title{
Genetic Analysis of the Green Cotyledon Trait in Southernpea [Vigna unguiculata (L.) Walp.]
}

\author{
Richard L. Fery ${ }^{1}$ and Philip D. Dukes ${ }^{2}$ \\ U.S. Vegetable Laboratory, Agricultural Research Service, U.S. Department of Agriculture, 2875 \\ Savannah Highway, Charleston, SC 29414 \\ Additional index words. blackeye bean, cowpea, green testa, allelism test, vegetable breeding
}

\begin{abstract}
A series of greenhouse and field studies were conducted to determine the inheritance of the green cotyledon trait exhibited by the recently released southernpea 'Bettergreen' and to elucidate the genetic relationship between the green cotyledon trait and the green testa trait exhibited by 'Freezegreen'. Evaluation of parental, $F_{1}, F_{2}$, and backcross populations of the crosses 'Bettergreen' $x$ 'Carolina Cream' and 'Bettergreen' $x$ 'Kiawah' indicated that the green cotyledon trait is conditioned by a single recessive gene. Evaluation of parental and $F_{2}$ populations of the cross 'Bettergreen' $x$ 'Freezegreen' indicated that this gene is neither allelic to nor linked with the $g t$ gene that conditions the green testa trait in 'Freezegreen'. The color of seeds harvested from plants homozygous for both the green cotyledon and green testa genes was superior and more uniform than the color of seeds harvested from either 'Bettergreen' or 'Freezegreen' plants. We propose that the newly discovered gene be designated green cotyledon and symbolized $\mathrm{gc}$. Seeds containing embryos homozygous for the $g c$ gene are easily identified. The ability to select in the seed stage should greatly facilitate efforts to backcross the $g c$ gene into cream-, pinkeye-, and blackeye-type cultivars.
\end{abstract}

The development of southernpea cultivars with a persistent green seed color has been the subject of much interest among both food processors, especially freezers, and plant breeders in recent years because seeds of such cultivars can potentially be harvested at the near-dry seed stage of maturity without loss of their fresh green color. The retention of the green color is important because the choice of harvesting method is often a compromise between cost and product quality. For example, once-over hand harvest, pea viner harvest, and axial-flow grain combine harvest result in about $50 \%, 20 \%$, and $12 \%$, respectively, high-quality fresh green peas (Fery, 1990). Although many processors blend peas from different harvest methods to maintain pack quality, the average blend pack now contains only $20 \%$ to $25 \%$ fresh green peas compared to the $40 \%$ to $50 \%$ averages common a few years ago (Fery, 1990).

Chambliss (1974) reported that the green testa gene ( $g t$ ) conditions a green seed coat color that persists in the dry seed, and this trait results in a processed product with improved consumer appeal. Fery et al. (1993) recently discovered a green cotyledon mutant in the cream-type cultivar Carolina Cream, and released a green cotyledon selection as 'Bettergreen'. 'Bettergreen' can be harvested at the near-dry stage of maturity without loss of the seed's fresh green color. This paper reports the inheritance of the green cotyledon trait and the genetic relationship between the green cotyledon and green testa traits.

\section{Materials and Methods}

The data reported here are from greenhouse and field experiments conducted at the U.S. Vegetable Laboratory, Charleston, S.C. Plants of the parental, $\mathrm{F}_{1}, \mathrm{~F}_{2}$, and backcross generations of the crosses 'Bettergreen' $x$ 'Carolina Cream' (cross A) and 'Bettergreen' $x$ 'Kiawah' (cross B) were evaluated for the green cotyledon trait. The parental and $\mathrm{F}_{2}$ generations of the cross

Received for publication 17 Aug. 1993. The authors wish to acknowledge the assistance of Agricultural Research Technicians F. P. Maguire and R. B. Cuthbert, II. The cost of publishing this paper was defrayed in part by the payment of page charges. Under postal regulations, this paper therefore must be hereby marked advertisement solely to indicate this fact.

${ }^{1}$ Research geneticist.

${ }^{2}$ Research plant pathologist.
'Bettergreen' x 'Freezegreen' (cross C) were evaluated for both the green cotyledon and green testa traits. 'Bettergreen' is homozygous for the gene conditioning the green cotyledon trait (Fery et al., 1993), and 'Freezegreen' is homozygous for the $g t$ gene conditioning the green testa trait (Chambliss, 1979). 'Kiawah' is a pinkeye-type cultivar that produces seed with cream-colored cotyledons and a cream-colored testa with a pink eye (Fery and Dukes, 1988). Except for the green cotyledon trait, 'Carolina Cream' and 'Bettergreen' are essentially isogenic lines (Fery and Dukes, 1984; Fery et al., 1993).

Seeds of the parental, $\mathrm{F}_{1}, \mathrm{~F}_{2}$, and backcross generations were produced in the greenhouse using standard crossing and selfing procedures. The pods were harvested immediately after reaching the dry stage, and the seeds were evaluated for cotyledon color after shelling. The parents and progeny of all three crosses were seeded in the field on 3 July 1991. The experimental design for evaluating the cross A and B populations was a modified, randomized complete block with four replications. Each replicate contained one plot of each of the parents, one plot of the $F_{1}$, one plot of the reciprocal $F_{1}$ (cross A only), and two plots each of the backcrosses and $\mathrm{F}_{2}$. The design of the experiment for evaluating cross $C$ populations was identical, except only the parental and $\mathrm{F}_{2}$ populations were included. Fifteen seeds per plot were planted $0.9^{2}$ $\mathrm{m}$ apart on beds $1 \mathrm{~m}$ apart. Standard cultural practices were followed in all three experiments.

All available dry pods on each field-grown plant in all three experiments were hand-harvested when about $95 \%$ of the total pods were dry. The genotype of each plant at the locus controlling the green cotyledon trait was subsequently determined by examination of the cotyledons in the harvested peas, which is essentially a progeny test because the cotyledons are part of the embryo component of the seed. If needed, a portion of the testa was removed to confirm cotyledon color. The genotype at the green testa $(g t)$ locus in all cross $C$ plants was determined by examination of testa color of the harvested seed (the testa develops from the integuments of the ovule and is maternal plant tissue).

\section{Results}

Examination of the seeds produced from the greenhouse cross- 
Table 1. Segregation for cotyledon color in parental, $F_{1}, F_{2}$, and backcross embryo populations of the crosses 'Bettergreen' $x$ 'Carolina Cream' (cross A) and 'Bettergreen' $x$ 'Kiawah' (cross B).

\begin{tabular}{|c|c|c|c|c|c|}
\hline \multirow[b]{2}{*}{ Population } & \multicolumn{2}{|c|}{$\begin{array}{c}\text { No. of embryos } \\
\text { in each class }\end{array}$} & \multirow{2}{*}{$\begin{array}{c}\text { Expected } \\
\text { ratios } \\
(\mathrm{G}: \mathrm{C})^{\mathrm{z}}\end{array}$} & \multirow{2}{*}{$\begin{array}{c}\text { Chi } \\
\text { square }\end{array}$} & \multirow[b]{2}{*}{$P$} \\
\hline & Green & Cream & & & \\
\hline \multicolumn{6}{|c|}{ Cross A } \\
\hline Bettergreen (BG) & 100 & 0 & All G & --- & --- \\
\hline Carolina Cream (CC) & 0 & 100 & All C & --- & --- \\
\hline $\mathrm{F}_{1}(\mathrm{BG} \times \mathrm{CC})$ & 0 & 11 & All C & --- & --- \\
\hline $\mathrm{F}_{1}(\mathrm{CC} \times \mathrm{BG})$ & 0 & 30 & All C & --- & --- \\
\hline $\mathrm{F}_{2}$ & 380 & 965 & $1 \mathrm{G}: 3 \mathrm{C}$ & 7.59 & $<0.01$ \\
\hline $\mathrm{F}_{1} \times \mathrm{BG}$ & 94 & 153 & $1 \mathrm{G}: 1 \mathrm{C}$ & 14.10 & $<0.01$ \\
\hline $\mathrm{F}_{1} \times \mathrm{CC}$ & 0 & 312 & All C & --- & --- \\
\hline \multicolumn{6}{|c|}{ Cross B } \\
\hline Bettergreen (BG) & 26 & 0 & All G & --- & --- \\
\hline Kiawah $(\mathrm{K})$ & 0 & 31 & All C & --- & --- \\
\hline $\mathrm{F}_{1}(\mathrm{~K} \times \mathrm{BG})$ & 0 & 7 & All C & --- & --- \\
\hline $\mathrm{F}_{2}$ & 55 & 189 & $1 \mathrm{G}: 3 \mathrm{C}$ & 0.79 & $0.5-0.2$ \\
\hline $\mathrm{F}_{1} \times \mathrm{BG}$ & 74 & 76 & $1 \mathrm{G}: 1 \mathrm{C}$ & 0.02 & $0.95-0.80$ \\
\hline $\mathrm{F}_{1} \times \mathrm{K}$ & 0 & 94 & All C & --- & --- \\
\hline
\end{tabular}

Table 2. Segregation at the green cotyledon locus in field-grown parental, $F_{1}, F_{2}$, and backcross populations of the crosses 'Bettergreen' $x$ 'Carolina Cream' (cross A) and 'Bettergreen' $x$ 'Kiawah' (cross B) as determined by an embryo progeny test of each individual plant.

\begin{tabular}{|c|c|c|c|c|c|c|}
\hline \multirow[b]{2}{*}{ Population } & \multicolumn{3}{|c|}{ No. of plants in each class } & \multirow{2}{*}{$\begin{array}{c}\text { Expected } \\
\text { ratios } \\
(\mathrm{G}: \mathrm{H}: \mathrm{C})^{\mathrm{z}}\end{array}$} & \multirow[b]{2}{*}{$\begin{array}{c}\text { Chi } \\
\text { square }\end{array}$} & \multirow[b]{2}{*}{$P$} \\
\hline & $\begin{array}{c}\text { omozygous } \\
\text { green }\end{array}$ & $\begin{array}{c}\text { Heterozygous } \\
\text { at locus }\end{array}$ & $\begin{array}{c}\text { Homozygous } \\
\text { cream }\end{array}$ & & & \\
\hline \multicolumn{7}{|c|}{ Cross A } \\
\hline Bettergreen (BG) & 46 & 0 & 0 & All G & --- & --- \\
\hline Carolina Cream (CC) & C) & 0 & 52 & All C & --- & --- \\
\hline $\mathrm{F}_{1}(\mathrm{BG} \times \mathrm{CC})$ & 0 & 23 & 0 & All H & --- & --- \\
\hline $\mathrm{F}_{1}(\mathrm{CC} \times \mathrm{BG})$ & 0 & 29 & 0 & All H & --- & --- \\
\hline $\mathrm{F}_{2}$ & 26 & 58 & 20 & $1 \mathrm{G}: 2 \mathrm{H}: 1 \mathrm{C}$ & 2.08 & $0.5-0.2$ \\
\hline $\mathrm{F}_{1}^{2} \times \mathrm{BG}$ & 54 & 49 & 0 & $1 \mathrm{G}: 1 \mathrm{H}$ & 0.24 & $0.8-0.5$ \\
\hline $\mathrm{F}_{1} \times \mathrm{CC}$ & 0 & 56 & 52 & $1 \mathrm{H}: 1 \mathrm{C}$ & 0.15 & $0.8-0.5$ \\
\hline \multicolumn{7}{|c|}{ Cross B } \\
\hline Bettergreen (BG) & 53 & 0 & 0 & All G & --- & --- \\
\hline Kiawah $(\mathrm{K})$ & 0 & 0 & 55 & All C & --- & --- \\
\hline $\mathrm{F}_{1}(\mathrm{~K} \times \mathrm{BG})$ & 0 & 26 & 0 & All H & --- & --- \\
\hline $\mathrm{F}_{2}$ & 30 & 44 & 34 & $1 \mathrm{G}: 2 \mathrm{H}: 1 \mathrm{C}$ & 3.99 & $0.2-0.05$ \\
\hline $\mathrm{F}_{1}^{2} \times \mathrm{BG}$ & 65 & 48 & 0 & $1 \mathrm{G}: 1 \mathrm{H}$ & 2.56 & $0.2-0.05$ \\
\hline $\mathrm{F}_{1} \times \mathrm{K}$ & 1 & 56 & 48 & $1 \mathrm{H}: 1 \mathrm{C}$ & 0.62 & $0.5-0.2$ \\
\hline
\end{tabular}

ing and seed-increase blocks suggested that the green cotyledon trait is conditioned by a single recessive gene (Table 1 ). None of the $F_{1}$ or reciprocal $F_{1}$ seeds of the 'Bettergreen' $x$ 'Carolina Cream' or 'Bettergreen' $x$ 'Kiawah' crosses contained embryos with green cotyledons. Cotyledon color in the $\mathrm{F}_{2}$ embryos of the 'Bettergreen' $x$ 'Carolina Cream' cross (cross A) approached a 1 green : 3 cream segregation ratio, the cotyledons in the $F_{1} x$ 'Bettergreen' backcross approached a 1 green : 1 cream segregation ratio, and all of the embryos in the $\mathrm{F}_{1} \mathrm{x}$ 'Carolina Cream' backcross exhibited cream cotyledons. Cotyledon color in the $\mathrm{F}_{2}$ embryos of the 'Bettergreen' $x$ 'Kiawah' cross (cross B) segregated 1 green : 3 cream, the cotyledons in the $F_{1} x$ 'Bettergreen' backcross segregated 1 green: 1 cream, and all of the embryos in the $\mathrm{F}_{1} \mathrm{x}$ 'Carolina Cream' backcross exhibited cream cotyledons.
Seeds harvested from the parental plants in the field experiments for evaluating the cross $\mathrm{A}$ and $\mathrm{B}$ populations contained embryos with the expected cotyledon phenotypes, i.e., 'Bettergreen', green cotyledons; 'Carolina Cream', cream cotyledons; and 'Kiawah', cream cotyledons (Table 2). The genotypes in the various generations of the 'Bettergreen' $x$ 'Carolina Cream' (cross A) and 'Bettergreen' $x$ 'Kiawah' (cross B) crosses as determined by cotyledon color of the progeny embryos indicated that the green cotyledon trait is clearly conditioned by a single recessive gene. All plants in the $\mathrm{F}_{1}$ populations were heterozygous at the locus conditioning the green cotyledon trait, and the $\mathrm{F}_{2}$ populations segregated 1 homozygous green : 2 heterozygous : 1 homozygous cream. Backcrosses of the $F_{1}$ to 'Bettergreen' segregated 1 green : 1 heterozygous, and backcrosses to the cream 
Table 3. Segregation for the green testa and green cotyledon traits in the parental and $\mathrm{F}_{2}$ populations of the cross 'Freezegreen' $\mathrm{x}$ 'Bettergreen'.

\begin{tabular}{|c|c|c|c|c|c|c|c|}
\hline \multirow[b]{3}{*}{ Population } & \multicolumn{4}{|c|}{ No. of plants in each class } & \multirow[b]{3}{*}{$\begin{array}{l}\text { Expected ratios } \\
(\mathrm{CC}: \mathrm{CG}: \mathrm{GC}: \mathrm{GG})^{\mathrm{y}}\end{array}$} & \multirow[b]{3}{*}{$\begin{array}{l}\text { Chi } \\
\text { square }\end{array}$} & \multirow[b]{3}{*}{$P$} \\
\hline & \multicolumn{2}{|c|}{ Cream testa } & \multicolumn{2}{|c|}{ Green testa } & & & \\
\hline & $\begin{array}{c}\text { Cream } \\
\text { cotyledon }\end{array}$ & $\begin{array}{c}\text { Green } \\
\text { cotyledon }\end{array}$ & $\begin{array}{l}\text { Cream } \\
\text { cotyledon }\end{array}$ & $\begin{array}{c}\text { Green } \\
\text { cotyledon }\end{array}$ & & & \\
\hline Freezegreen & 0 & 0 & 51 & 0 & All GC & $\begin{array}{ll}-- \\
\end{array}$ & --- \\
\hline Bettergreen & 0 & 48 & 0 & 0 & All CG & --- & --- \\
\hline $\mathrm{F}_{2}$ & 63 & 16 & 18 & 8 & $9: 3: 3: 1$ & 1.42 & $0.80-0.50$ \\
\hline
\end{tabular}

${ }^{\mathrm{z}}$ Segregation at the green testa locus was determined by evaluation of testa color of seed harvest from each plant; segregation at the green cotyledon locus was determined by evaluation of cotyledon color of progeny embryos.

${ }^{\mathrm{y}} \mathrm{CC}=$ cream testa and cream cotyledon, $\mathrm{CG}=$ cream testa and green cotyledon, $\mathrm{GC}=$ green testa and cream cotyledon, and $\mathrm{GG}$ $=$ green testa and green cotyledon.

cotyledon parents segregated 1 heterozygous : 1 cream. The single plant in the backcross to 'Kiawah' that produced seed with green cotyledons was probably the result of a seed mixture.

The segregation ratio in the $\mathrm{F}_{2}$ population from the 'Bettergreen' $\mathrm{x}$ 'Freezegreen' cross (cross C) ruled out both allelic and close linkage relations between the recessive genes conditioning the green cotyledon and green testa traits (Table 3 ). The observed ratio of 9 cream testa/cream cotyledon : 3 cream testa/green cotyledon $: 3$ green testa/cream cotyledon : 1 green testa/green cotyledon is the expected 4-class dihybrid ratio for two unlinked recessive genes. The color of seeds harvested from plants homozygous for both the green cotyledon and green testa genes was superior and more uniform than the color of seeds harvested from either 'Bettergreen' or 'Freezegreen' plants. The Munsell (1990) color ratings for 'Bettergreen', 'Freezegreen', and the double homozygote $F_{2}$ segregates were 7.5 Y $7 / 4,2.5 \mathrm{GY} 7 / 4$, and 10 Y 6/4, respectively.

\section{Discussion}

This study indicates that a single recessive gene conditions the green cotyledon trait exhibited by the recently released cultivar Bettergreen. We propose that this gene be designated green cotyledon and symbolized $g c$. The availability of this gene in an excellent cultivar background and the ability to select for the gene in the embryo stage should facilitate its use in breeding programs to convert standard cream-, pinkeye-, and blackeye-type southernpea cultivars to green cotyledon phenotypes. It should be noted that Magruder and Wester (1941) reported the discovery of a similar recessive gene in lima bean that conditions green cotyledons. Lima bean cultivars with green cotyledons have been popular in the frozen food industry for many years (Magruder and Wester, 1941; Wester, 1965).

Although the procedures used to determine the genotypes of field-grown plants at the $g c$ locus using embryo progeny tests were both rapid and reliable, some difficulty was encountered in determining the cotyledon phenotype of individual embryos in greenhouse-grown seed. The following phenomena seemed to account for most of the difficulties: 1) embryos heterozygous at the $g c$ locus have a tendency to retain some green pigmentation in the cotyledons if the seed are harvested immediately after pod dry-down, 2) the green color of the cotyledons of homozygous $g c / g c$ embryos has a tendency to gradually fade, probably because of extended exposure to light, if the seed remain on the plant for a significant amount of time after pod dry-down, and 3) the degree of pigmentation of the testa, and possibly testa thickness, seems to influence the effect of light on cotyledon color. Fading caused by exposure to light is not only a characteristic of green cotyledons in southernpea, but it has also been documented for green testa in southernpea, both green cotyledon and green seed coat in lima bean, and green seed coat in snap bean (Chambliss, 1974; Dean, 1968; Fery et al., 1993; Magruder and Wester, 1941; Tucker, 1965).

Our observation that plants homozygous for the recessive alleles at both the $g c$ and $g t$ loci might produce seeds that are superior in color to those produced by either 'Bettergreen' or 'Freezegreen' may be of considerable economic importance. This observation suggests that efforts should be initiated to study the feasibility of using both of these genes to develop cultivars that produce seed with an enhanced, persistent green color.

\section{Literature Cited}

Chambliss, O.L. 1974. Green seedcoat: A mutant in southernpea of value to the processing industry. HortScience 9:126.

Chambliss, O.L. 1979. 'Freezegreen' southernpea. HortScience 14:193.

Dean, L.L. 1968. Progress with persistent-green color and green seed-coat in snap beans (Phaseolus vulgaris L.) for commercial processing. HortScience 3:177-178.

Fery, R.L. 1990. The cowpea: Production, utilization, and research in the United States. Hort. Rev. 12:197-222.

Fery, R.L. and P.D. Dukes. 1984. 'Carolina Cream' southernpea. HortScience 19:456-457.

Fery, R.L. and P.D. Dukes. 1988. 'Kiawah' southernpea. HortScience 23:645-646.

Fery, R.L., P.D.Dukes, and F.P. Maguire. 1993. 'Bettergreen' southernpea. HortScience 28:856.

Magruder, R. and R.E. Wester. 1941. Green cotyledon, a new character in the mature lima bean (Phaseolus lunatus L.). Proc. Amer. Soc. Hort. Sci. 38:581-584.

Munsell Color. 1990. Munsell book of color: Glossy finish collection. Munsell Color, Baltimore.

Tucker, C.L. 1965. Inheritance of white and green seed coat colors in lima beans. Proc. Amer. Soc. Hort. Sci. 87:286-287.

Wester, R.E. 1965. Green cotyledon in lima beans: Its origin and development. Seed World 96(11):30. 